\title{
Women, Pleas and Property Crime: Understanding the Fortunes of Female Petitioners in London, 1819-1840
}

\author{
By David Orr*
}

\begin{abstract}
From a random sample of five-hundred petitions submitted (1819-1840) by felons convicted at the Old Bailey, only thirty-nine were female petitioners. This approximates the female-male felony ratio of convictions for felonious property crimes in London during this period. ${ }^{1}$ The thirty-nine female petitioners are the focus of this article. In particular, the article examines evidence and arguments suggesting that ideas of morality and social constructions of femininity and masculinity rather than legality most influenced the outcome of their appeals. Second, the article will examine the extent to which elite decision-makers used their ideals of motherhood, marriage status, and chastity to determine both the credibility of appeals and the moral integrity of the petitioners. Third, the article will examine how constructions of respectability were also applied to those who petitioned on behalf of female convicts and whether these ideas influenced the perception of the petitioner as credible. Ultimately, the article will conclude by assessing the degree to which subjective perceptions of petitioners and prisoners as moral or respectable determined who was deemed "fit subject of mercy."
\end{abstract}

\section{Introduction}

Historiography concerned with pre-Victorian pardoning processes has developed considerably since Hay's (1975) thesis and subsequent debates regarding powerful elites and mercy. Notably, the publication of Gatrell's Hanging Tree (1994/6) shifted focus to the agency of the accused and condemned. ${ }^{2}$ Additionally, several historians have noted that petitions for pardon or mitigation of sentence offer a rare insight into the lived experiences of some of the least powerful individuals in pre-Victorian society. ${ }^{3}$ Whilst not losing sight of why these documents were produced, which obviously meant certain aspects of the appellants' lived experiences were accentuated, it is wrong to simply dismiss the petitions as individualised, emotive and subjective. ${ }^{4}$ These petitions were a direct

*Senior Lecturer in Criminology, University of Central Lancashire, UK.

1. Peter King, Crime and Law in England 1750-1840 (Cambridge: Cambridge University Press, 2006), 172-175.

2. Simon Devereaux, "Execution and Pardon at the Old Bailey 1730-1837," American Journal of Legal History 57, no. 4 (2017): 490.

3. David Orr, "The Foul Conspiracy to Screen Salisbury and Sacrifice Morton': A Microhistory of Extortion, Resistance and Same Sex Intimacy in Early Nineteenth-century London," History: Journal of the Historical Association 103, no. 357 (2018): 572.

4. Alistair Thomson, "Four Paradigm Transformations in Oral History," The Oral History Review 34, no. 1 (2006): 52. 
interaction between some of the most powerful and least powerful people in preVictorian society. As such, female appellants and their advocates were fully aware of the need to reconstruct felons as fit subjects of mercy. In turn, this had a disciplinary effect upon the content of a petition. In the first instance then, the petitions tell us a great deal about pardoning processes. Second, the petitions tell us about the assumptions of the poorest concerning the morals and values of those to whom they were appealing. ${ }^{5}$ Third, the responses of elite decision makers tell us how the petitions were received and what specific moral, value and practical considerations informed decisions about the fate of female petitioners. Using this framework, the article explains why very few female petitioners received mitigation of their sentence despite apparent adherence to contemporary constructions of femininity. The paper examines evidence and arguments, suggesting constructs of morality rather than legality most influenced the outcome of the women's appeals, and how the assessment of the petitioner as a moral woman determined whether she was a fit subject of mercy.

\section{Literature Review}

Women and men in the early nineteenth-century were subject to and the subject of a moral and gendered discourse that had gained added impetus and currency in the final decade of the eighteenth-century. ${ }^{6}$ Dominant ideas regarding femininity suggested "that the public world was by definition coarsening and corrupting" for women and that women belonged in the home performing their gender as devoted mothers and wives. ${ }^{7}$ However, as Thompson noted, this was very much a middle-class idea of womanhood. Poor women rarely had the option to devote themselves to husbands and children, since their wages were

5. Ibid.," 52-54.

6. Françoise Barret-Ducrocq, Love in the Time of Victoria, trans. John Howe (LondonNew York: Verso, 1989), 29-33; Anna K. Clark, "Rape or Seduction? A Controversy over Sexual Violence in the Nineteenth Century," in The Sexual Dynamics of History: Men's Power, Women's Resistance, ed. The London Feminist History Group (London: Pluto Press, 1983), 14; Catherine Hall, "The Early Formation of Victorian Domestic Ideology," in Gender and History in Western Europe, ed. Robert Shoemaker and Mary Vincent (London: Hodder Education, 1998); Bridget Hill, Eighteenth-Century Women: An Anthology (London and New York: Routledge, 1993); Theresa M. McBride, The Domestic Revolution: The Modernisation of Household Service in England and France 1820-1920 (London: Croom Helm, 1976), 24; Roy Porter, English Society in the Eighteenth Century (London: Penguin Books, 1982), 35-45; Thompson, The Making of the English Working Class (London: Penguin, 1991), 60-61; Randolph Trumbach, Sex and the Gender Revolution (Volume One); Heterosexuality and the Third Gender in Enlightenment London (Chicago and London: The University of Chicago Press, 1998), 23-49.

7. Clark, "Rape or Seduction?," 15; Dorothy K. G. Thompson, British Women in the Nineteenth Century (London: The Historical Association, 1989), 8. 
required to sustain their families. ${ }^{8}$ Paradoxically, women in this situation were also expected to work. According to the same moral code that frowned upon women's participation in the public sphere, "work was the sole corrective and just retribution for poverty."9 Thus, poor women were expected to work, but without neglecting their familial duties, and in occupations "that coincided with a woman's nature sphere."10

As the century progressed, the occupational status and wage-earning power of poor women diminished, whilst the imperative to earn remained. Concurrently, expectations regarding familial roles increased. ${ }^{11}$ This created tension between middle class cultural expectations and the economic reality of working women's lives. It also meant that poor women were judged by a measure of femininity from which their poverty had excluded them, and which it was impossible for them to fulfil. They were neither permitted to be poor nor neglect their familial responsibilities lest they be deemed immoral, so were placed in an impossible situation whereby the contradictory elements of middle-class moralism could not be satisfied without risking the censure of that class. ${ }^{12}$ Hence, petitioners believed that activities outside the family, including crime, had to be presented as an extension of femininity and familial responsibilities, so as not to compromise the Home Department's perception of the convict as a good woman. ${ }^{13}$

Historiography concerned with women and crime in late eighteenth, early nineteenth-century has been cognisant of these issues. However, research has

8. Thompson, British Women, 9-10; This point is also made by Hill, Eighteenth-Century Women, 5. McBride, The Domestic Revolution, 27, adds that as the century progressed "the middle class work and family ethic gradually permeated most levels of society." Francis Place also commented on this paradox, British Library [BL] Add.35142: f.94, The Artisan's London and Provincial Chronicle, July 1825; [BL] Add.35142: f.95, "Political Economy," Trade News and Mechanic's Weekly Journal, 14.08.1825; [BL] Add.35142: f.111, "Mr Hale's Address on a Minimum of Wages," Trade News and Mechanic's Weekly Journal, 21.05.1826.

9. Sally Alexander, Women's Work in Nineteenth-century London: A Study of the Years 1820-1850 (London: The Journeyman Press and The London History Workshop Centre, 1983), 11.

10. Ibid., 12.

11. Thompson, British Women, 11.

12. Porter, English Society, 45-48.

13. Clark, "Rape or Seduction?," 18-19, makes a similar point regarding judgements of Mary Ashford's character following her murder by Abraham Thornton; Also see BarretDucrocq, Love in the Time of Victoria, 53-54. 
Vol. 6, No. 2 Orr: Women, Pleas and Property Crime: Understanding the Fortunes...

largely focused upon women as victims or women who worked as prostitutes. ${ }^{14}$ In cases of felony, King has claimed that women were treated more leniently than their male counterparts. If this were the case, women's pleas for mitigation of sentences would have been largely successful. ${ }^{15}$ Yet, only one woman from the entire sample examined here received mitigation for anything other than ill health or commutation of a capital sentences. King's sample was taken from Home Circuit cases, so it is possible that a less harsh view of female felons prevailed amongst provincial jurors. ${ }^{16}$ London had a specific and greater crime problem than the provinces, and this could account for differences in reporting, decision-making and conviction. ${ }^{17}$ In support of this argument, Beattie has shown that there it was a larger proportion of female defendants in early eighteenthcentury London, although numbers of female defendants fell after $1750 .{ }^{18}$ Additionally, these women were mostly prosecuted for misdemeanour. ${ }^{19}$

Thus, even in London convicted female felons represented a very small minority of the most serious criminal cases. ${ }^{20}$ It follows that the capitally convicted women constituted an even smaller proportion of those sentenced to hang. However, Beattie and Gatrell both argue that Londoners were increasingly squeamish and sentimental about whipping and hanging female felons. Gatrell cites the substantial campaigns concerning the Sarah Lloyd and Eliza Fenning

14. Robert Shoemaker, "Forty Years of Crime in London," The London Journal 40, no. 2 (2015): 93-94; Gregory Durston, Victims and Viragos: Metropolitan Women, Crime and the Eighteenth Century Justice System (Bury St Edmonds: Abramis Press, 2007), 197-224; Tony Henderson, Disorderly Women in Eighteenth-Century London: Prostitution and Control in the Metropolis, 1730-1830 (Harlow: Longman Press, 1999); Judith R. Walkowitz, City of Dreadful Delight: Narratives of Sexual Danger in Late-Victorian England (London: Virago Press, 1992), 21-22.

15. King, Crime, Justice and Discretion in England 1740-1820 (Oxford: Oxford University Press, 2000), 279.

16. John M. Beattie, Policing and Punishment in London 1660-1750: Urban Crime and the Limits of Terror (Oxford: Oxford University Press, 2001), 20.

17. See ibid., 1; Alan Brooke and David Brandon, Tyburn: London's Fatal Tree (Stroud: Sutton Publishing, 2004), 108-109; Clive Emsley, Crime and Society in England 1750-1900 (Harlow: Longman Press, 1996), 60-64; V.A.C. Gatrell, The Hanging Tree: Execution and the English People 1770-1868 (Oxford: Oxford University Press, 1996), 6-11; Heather Shore, Artful Dodgers: Youth and Crime in Early 19th Century London (Woodbridge: The Boydell Press, 1999/2002), 2-4; John J. Tobias, Crime and Industrial Society in the Nineteenth Century (London: Pelican Books, 1972), 26-56.

18. Beattie, Policing and Punishment, 63-71.

19. Shoemaker, Prosecution and Punishment: Petty Crime and the Law in London and Rural Middlesex c1660-1725 (Cambridge: Cambridge University Press, 1991), 212-213; Gwenda Morgan and Peter Rushton, Rogues, Thieves and the Rule of Law: The Problem of Law Enforcement in North-East England (London: UCL Press, 1998), 67-68, 97-123.

20. Beattie, Policing and Punishment, 296-299. 
cases, to evidence this point. ${ }^{21}$ The result, they claim, was a reticence to convict women for capital crimes and a tendency towards more lenient sentencing.22 Three women in the sample discussed here were capitally convicted. All three had their sentences commuted to transportation for life. Maria Williams was convicted for uttering a forged banknote and Honor Baldwin for stealing various valuable items from the dwelling house of the Earl of Belfast. ${ }^{23}$ As Devereaux notes, commutation for both offences had become standard by the late 1820s. Therefore, these commutations were neither exceptional nor indicative of greater leniency towards women. ${ }^{24}$ Only the commutation of Mary Jackman's capital sentence requires further discussion. On 30 th June 1831, Mary Jackman was convicted of violently robbing Henry McFarlin, four days before at her house in Goswell-street, St Luke's, London. McFarlin was taken to the house by Mary Ann Gray, also known as "Country Polly," after meeting Gray in a nearby public house. In the process of stealing eighteen shillings McFarlin claimed, "Jackman was holding me by the collar with one hand all the time, and striking me as hard as she could, like a man." 25 The gendered description of violence was obviously used to denote its seriousness, and perhaps to preserve the victim's dignity by suggesting Jackman was unnaturally strong. Despite Jackman's plea at trial, that she was "as innocent as an unborn baby;"26 her petition was nothing more than a statement of character from the parishioners of St Luke's. ${ }^{27}$ A man who had effectively admitted using such force as to threaten murder during a robbery may well have hanged, but Mary Jackman's sentence was commuted to "Transportation for Life."28 This is the only possible support in the sample for Gatrell and Beattie's argument, but it is hardly conclusive. What is more, there was no campaign for the life of Mary Jackman, as there had been for Sarah Lloyd and Eliza Fenning. A woman who used violence "like a man" was hardly going to attract such sentimental attention. Conversely, unwillingness to address violence against women in the home gave license "to men to use violence in particular

21. For full details of these cases and attendant campaigns for commutation, see Gatrell, Hanging Tree, 339-370.

22. Beattie, Policing and Punishment, 362; Gatrell, Hanging Tree, 334-338.

23. Old Bailey Proceedings Online [OBSP] Case 262, $14^{\text {th }}$ January 1824: Trial of Maria Williams, accessed 13 February 2015; [OBSP] Case 281, 11 th January 1827: Trial of honor Baldwin, accessed 13 February 2015.

24. Devereaux, "Execution and Pardon," 477-478.

25. [OBSP] Case 1210, 30 $0^{\text {th }}$ June 1831: Trial of Thomas Haywood, Mary Jackman, Hannah Graham and Phoebe Hymans, accessed 13 February 2015.

26. [OBSP] Case 1210, 30th June 1831, accessed 13 February 2015.

27. The National Archive [TNA] HO 17/17 (1) Bg 1: "The Humble Petition of Mary Jackman, convicted at the June session 1831 for robbery and sentenced to death."

28. [TNA] HO 17/17 (1) Bg 1: "The Humble Petition of Mary Jackman," June 1831. 
'domestic' contexts." 29 So, in contrast to Mary Jackman's violence, violence of male partners was mostly ignored as an explanation for the criminality of female petitioners because it conformed to gendered expectations of behaviour.

The following discussion of petitions submitted by women convicted of noncapital felonies will test these arguments. Particularly, the case of Elizabeth Holland will be closely examined to understand why her petition succeeded when the pleas of her peers did not. The paper will then go on to highlight the failings of the remaining petitions to argue that intersections between women's experience, social class, gendered social constructs and non-legal elite decision were much more complex than either Gatrell or Beattie indicated.

\section{Methodology}

At one level, the research is concerned with documenting the view from below. The petitions offer a window into the lives of women previously undocumented and rarely heard from in historical documents. ${ }^{30}$ More than this, the petitions bear witness to the interconnection between individual and collective experience, and the social expectations and beliefs that framed how the women reinterpreted events in their lives for the purposes of their plea. Thus, petitions signify the agency of female convicts or their advocates whilst revealing dominant contemporary ideas of femininity and appropriate behaviour that shaped appeals for mercy. ${ }^{31}$ In order to examine this relationship, a representative sample of thirty-nine petitions submitted by or on behalf of women convicted at the Old Bailey, 1819-1840, was examined. The petitions were taken from a larger random sample of 500 petitions submitted by both men and women and approximate the female-male felony ratio of convictions for property crimes in London at this time. ${ }^{32}$ Whilst it is tempting to view the experiences and articulations of the petitioners as "representative or ordinary," one must be mindful of the circumstances under which the pleas were produced. For this reason, the voice of female petitioners is understood as "specific and

29. John Carter Wood, Violence and Crime in Nineteenth-century England: The shadow of our refinement (London: Routledge, 2004), 110.

30. Thomson, "Four Paradigm Transformations," 51-52.

31. Ibid., 55-56; Polly Russell, "Using Biographical Narrative and Life Story Methods to Research Women's Movements: Sisterhood and after," Women's Studies International Forum 35, no. 3 (2012): 132-134; Cynthia Richards, "Women of Quality: Accepting and Contesting Ideas of Femininity in England, 1690-1760," The Scriblerian and the Kit-Cats 36, no. 2 (2004): 182-183; Carolyn Malone, "Women in England 1760-1914: A Social History," Journal of Victorian Culture 12, no. 1 (2007): 132.

32. King, Crime and Law in England, 172-175. For full details of the sample see appendix. 
extraordinary."33 However, dominant social constructions of femininity and woman that mark the self-conscious content and construction of the petitions are discussed in terms of their disciplinary effect upon the lives of women and men more generally.

By taking a microhistory approach, the focus shifts from the discussion of elites and statistical evidence to examine how individual women sought to negotiate their sentence through the petition process. This enables an examination of varied experiences and realties of pre-Victorian criminal justice. ${ }^{34}$ Individual experience and action offer a further key to understanding the complex interaction between actors' choices and their understanding of contemporary narratives concerning femininity and gender. Hence, the methodological approach adopted goes beyond a situational understanding of the cases presented to reveal previously "unobserved factors endemic" to the society in which the women lived. ${ }^{35}$ Finally, it is worth noting that few petitions in the sample resulted in mitigation. Excepting the three capital commutations and one mitigation of sentence on mental health grounds, only one non-capital case in the sample, that of Elizabeth Holland, was positively received. The remainder of the paper will discuss why Elizabeth Holland was successful. It will also shed some light on why her co-appellants were not, and the key strategies women used to re-construct themselves as appropriate females and fit subjects of mercy.

\section{Findings and Commentary}

In December 1826, Elizabeth Holland was convicted at the Old Bailey for theft from a specified place. She was sentenced to seven years transportation. According to her petitioner, Ann Betley, Elizabeth "in want of the common necessities of life 'was' induced to pawn a sheet for two shillings" taken from her lodgings. ${ }^{36}$ Elizabeth had worked hard as a shoe binder. She was poorly paid, and work was increasingly scarce due to the decline in London's traditional crafts and industries. ${ }^{37}$ Whilst want was common as the basis of pleas for mitigation, it is

33. Russell, "Using Biographical Narrative," 134.

34. Orr, "The Foul Conspiracy," 573; Rachael Griffin, "Bobbies, Booze and Bagatelle: Policing Vice in Early Victorian London," in Law, Crime and Deviance since 1700: MicroStudies in the History of Crime, ed. Anne-Marie Kilday and David Nash (London: Bloomsbury Academic Press, 2017), 192, 201.

35. Laurie Marhoefer, "Lesbianism, transvestitism, and the Nazi state: a microhistory of Gestapo investigation, 1929-1945," American Historical Review 121, no. 6 (2016): 1172.

36. [TNA] HO 17/15 (2) Bm 10: "Letter from Ann Betley to Robert," December 19th, 1826.

37. [TNA] HO 17/15 (2) Bm 10: "Letter from Ann Betley," Iorwerth J. Prothero, Artisans and Politics in Early Nineteenth-century London: John Gast and His Times (Grantham: Methuen Press, 1979), 210-225. 
clear from the outset of the petition that Ann Betley had a distinct and conscious strategy. Rather than simply relying on pity, Ann sought to distinguish Elizabeth from those women who, in the eyes of the Home Department, did not deserve mercy. To these ends, the substantive part of the petition focused on Elizabeth's previous good character and the respectability of her family. Again, this was not unusual for petitions of the period, but the discussion of previous good character in this instance needs to be understood in the context of the whole petition. Hence, Ann stated that Elizabeth's family,

"Have been respectable the Father having lived for 22 years as Head Gardner in the Family of Mr Bruce of Brompton but who is now dead, and the mother died only two months ago leaving several children."38

Elizabeth was twenty-two years old when convicted. She had spent most of her life in and around the Bruce residence before moving to London with her sister, of whom Ann Betley wrote, "has lived servant with me for the last two years, and who is now in my service."39 Without stating it directly, Ann established that Elizabeth came from an honest and industrious family, and by association she was accorded the habits, industry and character of her trusted sister. Their family had also been financially dependent upon Elizabeth and her sister since the death of their mother. Ann Betley thus contested the construction of Elizabeth Holland as a felon beyond moral redemption or reformation. The petitioner went on to states that Elizabeth lived in a "lodging house for young women."40 Again, rather than making a direct statement, the intimation here is that Elizabeth was chaste, so as well as being honest and industrious she was also virtuous. This was crucial to the success of the petition. Although written eight years after Ann Betley's petition, Chitty's comment in Treatise, 1834, summed up the prevailing attitude stating that,

"Universally, in England, an unmarried woman who has had sexual intercourse, even by such force that she was unable to resist with effect, is in a degree disgraced, or rather no longer retains her virgin purity in the estimation of society, and there is a natural delicate, though perhaps indescribable feeling that deters most men who know that female has been completely violated, from taking her in marriage." 41

38. [TNA] HO 17/15 (2) Bm 10: "Letter from Ann Betley."

39. [TNA] HO 17/15 (2) Bm 10: "Letter from Ann Betley."

40. [TNA] HO 17/15 (2) Bm 10: "Letter from Ann Betley."

41 Joseph Chitty, "A Practical Treatise on Medical Jurisprudence...," (London: Sold by Longman, Rees, Orme, Brown, and Green, 1834), 378. Quoted in Clark, "Rape or Seduction?," 24. 
Consequently, in the opening sentences of the petition Ann Betley has succeeded in reconstructing Elizabeth Holland, female convict, as a paragon of middle-class morality. Clearly and understandably, Ann's petition reflected the dominant cultural script that informed assumptions regarding femininity and the socially constructed "good woman" of early nineteenth-century Britain. ${ }^{42}$ The petition did not seek to challenge this script, but rather to present Elizabeth Holland to the Home Department as a moral and "appropriate" woman, despite her circumstances.

However, previous good character did not generally weigh as heavily with the Home Department as subsequent legal transgressions. So, Ann moves next to discuss the theft for which Elizabeth was convicted. Ann began her defence by stating that Elizabeth came by, "the property in her possession, not by theft she being a lodger and the money obtained being only two shillings I hope and trust will be sufficient apology for this supplication."43 The petition does not deny Elizabeth took the sheets, but Ann questions the perception of Elizabeth as a thief. Elizabeth's transgression is neither heinous nor serious, nor is Elizabeth really a thief as far as Ann is concerned. Therefore, she feels compelled to write, "To save this unfortunate young creature, from total ruin, which must ultimately be the case if transported with class of Females who are sent out of the Country."44 This "class of Females" was not defined but were clearly meant to represent the antithesis of Elizabeth's chaste, virtuous and industrious character. The dominant cultural script also defined these other women. They were the unchaste, supporting themselves with crime and sex, and were the converse of the so-called appropriate or moral woman. Again, the petition does not challenge the dominant cultural script there are women who deserve transportation, Ann Betley makes clear, but Elizabeth Holland is not of that other "class of females."

Ann had only one point to add to her petition, but it was critical to the success of Elizabeth's plea. At the end of the petition, Ann also implies that Elizabeth will not be led back into criminality because, "I on her release will most cheerfully receive her into my service being satisfied from her family and general conduct that nothing but the greatest distress prompted her to commit the crime." 45

The fact that Ann Betley was a wealthy woman living in Little Chelsea was crucial to the success of Elizabeth's petition. Ann knew what the bureaucrats at the Home Department needed to read if they were to commute Elizabeth's sentence. She wrote the petition without sycophancy or sentimentality and addressed Peel as her social equal, without telling him directly how to do

42. Hall, "The Early Formation," 181-197.

43. [TNA] HO 17/15 (2) Bm 10: "Letter from Ann Betley."

44. [TNA] HO 17/15 (2) Bm 10: "Letter from Ann Betley."

45. [TNA] HO 17/15 (2) Bm 10: "Letter from Ann Betley." 
his job. The offer of work for Elizabeth was not tenuous or unstable, but promised secure employment in a large house, where Elizabeth's behaviour would be under constant scrutiny. It ensured that Elizabeth would not find herself without income on release from her sentence, and it displayed Ann trusted Elizabeth enough to employ her in a situation where she will have access to Ann's property. On the back of the petition was scribbled "Is there any credit due to the writer of this letter," which indicates that enquiries were made about Ann Betley. ${ }^{46}$ Once her character and social status were established, Ann's confidence in Elizabeth encouraged the Home Department to grant mercy, and Elizabeth's punishment was commuted to a shorter prison sentence.

Clearly, the strategy and status of Elizabeth Holland's petitioner were deciding factors in the mitigation of her sentence. But, how does this petition compare to the those of the other women in this sample who failed to be granted mitigation? To begin with, most of the other women in the sample petitioned on their own behalf using the services of an advocate or scribe or their petitioner did not have Ann Betley's social standing. In other words, they did not have an individual considered respectable representing their case in such a calculated way. Second, most petitions attempted to arouse the pity of elite decision makers rather than distinguish themselves as special cases. But these were not merely emotive and subjective appeals. Whether consciously or not, petitioners also reconstructed offending and the convict within what they believed to be the ideas of femininity and respectability held by those to whom they appealed. To these ends, many female petitioners focused upon their experiences as mothers and wives to illustrate their femininity and demonstrate their moral character. This accounts for the frequency with which children were mentioned in the petitions of female prisoners. Of the thirty-nine female convicts in the sample, fifteen of their petitions suggested or implied that the Home Department should consider children as mitigation against legal transgressions or given sentences. Maria Fillingham's petition is typical of many petitions in the sample. Petitioner George Barton stated that Maria's husband,

"Thrust her and her children out of doors! Thereby exposing them to misery, destitution and want [to become] a wanderer and compelled to seek a precarious livelihood for herself and her family." 47

Likewise, Honor Baldwin's petitioner stated that he was, "Fully convinced that absolute want induced her to commit this act...having 3 children almost

46. [TNA] HO 17/15 (2) Bm 10: "Letter from Ann Betley."

47. [TNA] HO 17/15 (2) Bm 9: "Letter sent by George Barton, 5 $5^{\text {th }}$ February 1827, on behalf of Maria Fillingham who was convicted of larceny at December session 1826 and sentenced to 7 years transportation." 
starving."48 Mary Day's petition states that she was "driven" to steal the books, for which she was sentenced to seven years transportation, "By the sight of her infants in actual want of nourishment."49

In this way, property offences committed by the women were, consciously or not, presented as an extension of her mothering role, and thus consistent with dominant ideas regarding femininity. The statements made by these women in their petitions were borne out of real experiences. The prisoners, or those advocating on their behalf, were acutely aware of the need to present themselves as good female characters even though they had transgressed the law. Since legal transgression was additionally a transgression of dominant constructions of femininity, the offence had to be represented as an extension of a woman's accepted role if a plea was to be accepted. Thus, a mothers' sacrifice for the sake of children was one way a female prisoner attempted to salvage her character. For this to work, though it rarely did, the petitioners had to make it clear that, through no fault of their own, they had become solely responsible for the care and upkeep of their children. For this reason, several women discuss violent and estranged husbands to explain how the circumstances of their offence had occurred. In Maria Fillingham's case, her petition explains her transformation from a woman who "had conducted herself with great propriety and respectability' to a twice convicted felon as a "consequence of the brutal usage she has received from her husband." It goes on to state that,

"[Maria's husband] very soon after their marriage cohabited with another Woman by whom he has a family and has been Married to a second Wife by whom he has a family also-! this adding the crime of Bigamy to his other vices she [Maria] has been a lost woman -coupled with this is the personal violence she has experienced- the many times he has endangered her life." 50

Still Maria did not leave the family home until; she was "thrust" out by her husband. In other words, her loss of character was purely a result of her husband's actions. By this, Maria hoped to demonstrate that she was not an incorrigible criminal undeserving of mercy, and her legal transgression should in no way cast aspersions upon her character as a conscientious mother and loyal wife. In fact, Maria hints that if she had been less loyal and conscientious, she would not have fallen into committing larceny to feed her children.

48. [TNA] HO 17/15 (2) Bm 15: "Note from the Earl of Belfast, 22 ${ }^{\text {nd }}$ January 1827 in favour of Honor Baldwin, convicted of stealing in a dwelling house at January session 1827 and sentenced to death." Tasmanian Record Office [TRO] HO11/6, 216, state that Honor travelled with her husband James and 3 children to Van Diemen's Land in 1827, received a condition pardon in 1836, and died in Van Diemen's Land in 1859.

49. [TNA] HO 17/16 Bo 44: "Petition sent to Robert Peel by Mary Day, convicted at the February session 1829 for stealing books and sentenced to 7 years transportation."

50. [TNA] HO 17/15 (2) Bm 9: "Letter sent by George Barton." 
Vol. 6, No. 2 Orr: Women, Pleas and Property Crime: Understanding the Fortunes...

Similarly, according to her petition Mary Wilson had given her a "moral" education, but things went wrong when she married "a man of loose morals and dissolute conduct." 51 Mary Day was taught honest and industrious habits by her parents and would have been able to support herself and her family "but for the profligacy and indiscretion of an unfeeling husband" who abandoned her and their three children "leaving them in distress and want."52 A variant on this theme is presented by seventeen-year-old Elizabeth Wheatley. Elizabeth did not have children, but she had attempted suicide because of the "inhumane manner" with which her husband had treated her. The theft of two silver spoons was committed whilst she was "in a state of the most abject wretchedness and starvation through the disgraceful conduct of her husband" who was known "to keep her on very little food for weeks." ${ }^{33}$ In all these cases, the situation presented to the Home Department was beyond the control of the women seeking commutation. These were women, the petitions claim, that were forced to commit crime because of ill-treatment by men upon whom the family were financially dependent. ${ }^{54}$

These petitions demonstrate the disciplinary effect of ideas of femininity believed to be held by elite decision-makers. They also demonstrate the poor woman's inability to fulfil the contradictory elements of dominant moralist discourse that expected women to be responsible for their own poverty and, at the same time, their families. By presenting experiences of male violence, it could at least be argued that they were not responsible for their own poverty or legal transgressions. Their offences were thus actively presented as the actions of desperate mothers trying to survive and feed their children, and not a product of their immorality.

No doubt, some petitioners exaggerated their circumstances. After all, the women in the sample were pleading to avoid execution or transportation. At the same time, interpersonal violence was ubiquitous in many women's lives. These experiences alongside expectations of women as primary carers of children

51. [TNA]HO 17/2 (1): "Petition of Mary Wilson, convicted of stealing from the shop of Mr Harvey, linen draper, and sentenced to 14 years transportation." Sent by a number of "householders" from Southwark and Bishop's Gate, October 1826.

52. [TNA] HO 17/16 Bo 44: "Petition sent to Robert Peel by Mary Day."

53. [TNA] HO 17/15 (2) Bm 14 (1): "Petition sent to Robert Peel from James Leggett (prosecutor) on behalf of Elizabeth Wheatley, convicted for larceny at the December session 1826, and sentenced to 7 years transportation," and (2) "Petition sent to Robert Peel from Ann Turner [Elizabeth's mother] on behalf of Elizabeth Wheatley, convicted for larceny at the December session 1826, and sentenced to 7 years transportation," February $26^{\text {th }} 1827$.

54. Thompson, British Women, 12. 
evidently shaped the material circumstances of female petitioners' lives. ${ }^{55}$ However, the mention of children often went against female prisoners because of contemporary beliefs that criminal parents infected their progeny with immorality and criminality. ${ }^{56}$ This idea had been gaining currency in the eighteenth-century but was particularly strong in the 1820 s and 30s. ${ }^{57}$ Given dominant ideas regarding femininity, this obviously placed women at the forefront of producing moral children. Thus, in the minds of those deciding her fate a convicted mother broke expected norm in her own right and threatened the morality of future generations. These were Ann Betley's other "class of females," for whom the system of transportation was set up to banish from their native country. ${ }^{58}$ Thus, for female petitioners to state that they had children without denying their guilt was more likely to alarm the home department than induce mercy. This evident mismatch between petitioners' assumptions and the specific moral and practical considerations of Home Department elites clearly explains why most petitions in the sample were rejected.

In some instances, ratepayers who signed the women's petitions encouraged appellants to foreground experiences of interpersonal violence and childcare responsibilities. The agendas of middling ratepayers were themselves complex, and often conflicted with national policy where higher rates and local issues were concerned.59 Whilst ratepayers supported the general removal of felons, they petitioned against transportation when the sentence promised to place dependants upon the parish. ${ }^{60}$ Hence, ratepayerswere encouraged to support the petitions of female felons with children, particularly those women who were sole carers, as their execution or transportation equated to increased legal and financial responsibility. Where very young children were concerned, transport with their mother was less likely because of cost, arduousness of transportation and burden placed upon penal colonies. Therefore, these petitions prompted most support from local ratepayers because the children involved were most likely to become dependants upon the parish. Against this, national policy was also governed by cost. In New South Wales and Van Diemen's Land, children born in colonies

55. Barret-Ducrocq, Love in the Time of Victoria, 45-50; Clark, "Rape or Seduction?," 2021; Gatrell, Hanging Tree, 465; Morgan and Rushton, Rogues, Thieves and the Rule of Law, 5758; Martin J. Wiener, Reconstructing the Criminal: Culture, Law and Policy in England, 18301914 (Cambridge: Cambridge University Press, 1990), 282-283.

56. Barret-Ducrocq, Love in the Time of Victoria, 180-181; Shore, Artful Dodgers, 23.

57. Beattie, Policing and Punishment, 51; King, Crime, Justice and Discretion, 284-285.

58. Robert Hughes, The Fatal Shore (London: Vintage Books, 2003), 244-245; Weiner, Reconstructing the Criminal, 53, 254.

59. David Churchill, Crime Control \& Everyday Life in the Victorian City: The Police and the Public (Oxford: Oxford University Press, 2017), 98-111; Orr, "Crime Control \& Everyday Life in the Victorian City: The Police and the Public," Cultural and Social History 16, no. 3 (2019): 1-2.

60. King, Crime, Justice and Discretion, 283-284. 
were proving to be a financial and organisational burden. ${ }^{61}$ Additionally, women sentenced in the 1820 s and 30 s to seven years transportation were more likely to be transported than men under the same sentence. ${ }^{62}$ This was partly because of a demand for female convict labour amongst free settlers that no longer existed for male prisoners. ${ }^{63}$ Therefore, the upkeep of female convicts was often met by the free settlers in Australia, except when the prisoner has attempted escape. ${ }^{64}$

\section{Conclusion}

It was into this complex set of relationships and competing interests that female petitioners tried to present themselves as fit subjects for mercy or pity. Elizabeth Holland's petition said no more in mitigation of her sentence than those of the female petitioners who failed to gain commutations, but the way it was constructed, by whom it was constructed and the prospect it offered Elizabeth of leading an industrious and virtuous life without cost to the ratepayer or the treasury were the factors crucial to her obtaining commutation of her sentence. Elizabeth's petition clearly demonstrates, as do the petitions of all the women discussed, how dominant ideas of femininity and gendered morality circumscribed both women's lives and elite decision-making regarding pleas for mercy. ${ }^{65}$ The petitions also demonstrate the central importance of class. Increasingly powerful middle classes established the moralist agenda as a codification of acceptable behaviour, and it was the intervention of socially and economically elite supporters that made the difference between success and failure of a petition. Lastly, in all cases, the poverty of female petitioners led them to transgress the law in the first place. That these women were judged through a gendered filter of moralism is clear. At no time does the sentimental attitude towards punishing women, discussed by Gatrell, appear to have influenced the treatment of female petitioners in this sample. Indeed, there appears to have been no attempt to respond to female convicts and their families as human beings

61. Brooke and Brandon, Bound for Botany Bay: British Convict Voyages to Australia (London: The National Archives, 2005), 80-81.

62. George P. Holford, Letters to the Editor of the Quarterly Review on a Misstatement Contained in the 42D Volume of that work...Relative to the Supposed Ill-success of the General Penitentiary at Millbank (London: Rivington's, 1830), 31; Morgan and Rushton, Rogues, Thieves and the Rule of Law, 157-161; Alan G.L. Shaw, Convicts and the Colonies, a Study of Penal Transportation from Great Britain and Ireland to Australia and Other Parts of the British Empire (London: Faber and Faber, 1966), 100-101.

63. Holford, Letters to the Editor of the Quarterly Review, 35; Hughes, Fatal Shore, 263; Shaw, Convicts and the Colonies, 196.

64. Hughes, Fatal Shore, 253-258.

65. Shoemaker, Gender in English Society 1650-1850 (New York and London: Routledge Taylor and Francis Group, 1998/2013), 316-318. 
faced with tragic situations. The bureaucratic rational that circumscribed decision-making on pleas for mercy served only to compound these tragedies and removed the last vestiges of hope for a reprieve. That most women who transgressed the law were dealt with by justices and magistrates earlier in the prosecution process, suggests that mitigating factors had already been considered and ruled out. ${ }^{66}$ Therefore, this made the situation of female felons even more hopeless. Not only were they viewed as the dregs of womanhood by elite decision-makers, they were, at the time of writing their petitions, cast as the most undeserving of female lawbreakers. In this context, there was little hope of receiving mercy. Thus, legal processes re-enforced dominant ideas of middleclass respectability, morality and femininity. Those female petitioners who did not fit with these ideas were promptly and physically removed from English society.

\section{Acknowledgements}

Many thanks to Dr Jane Attfield for her help, support and suggestions, to Professor David Wick, Professor Henri Dural and Dr. Kenneth Moore for their encouragement during the process of writing this article, and to the anonymous reviewers for their helpful comments and suggestions.

\section{Bibliography}

Alexander, Sally. Women's Work in Nineteenth-century London: A Study of the Years 1820-1850. London: The Journeyman Press and The London History Workshop Centre, 1983.

Barret-Ducrocq, Françoise. Love in the Time of Victoria. Translated by John Howe. London-New York: Verso, 1989.

Beattie, John M. Policing and Punishment in London 1660-1750: Urban Crime and the Limits of Terror. Oxford: Oxford University Press, 2001.

Brooke, Alan, and David Brandon. Tyburn: London's Fatal Tree. Stroud: Sutton Publishing, 2004.

Brooke, Alan, and David Brandon. Bound for Botany Bay: British Convict Voyages to Australia. London: The National Archives, 2005.

Carter Wood, John. Violence and Crime in Nineteenth-century England: The shadow of our refinement. London: Routledge, 2004.

Churchill, David. Crime Control E Everyday Life in the Victorian City: The Police and the Public. Oxford: Oxford University Press, 2017.

66. Beattie, Policing and Punishment, 444; King, Crime, Justice and Discretion, 287; Shoemaker, Prosecution and Punishment, 149. 
Vol. 6, No. 2 Orr: Women, Pleas and Property Crime: Understanding the Fortunes...

Clark, Anna K. "Rape or Seduction? A Controversy over Sexual Violence in the Nineteenth Century." In The Sexual Dynamics of History: Men's Power, Women's Resistance, edited by The London Feminist History Group, 13-27. London: Pluto Press, 1983.

Devereaux, Simon. "Execution and Pardon at the Old Bailey 1730-1837." American Journal of Legal History 57, no. 4 (2017): 447-494.

Durston, Gregory. Victims and Viragos: Metropolitan Women, Crime and the Eighteenth Century Justice System. Bury St Edmonds: Abramis Press, 2007.

Emsley, Clive. Crime and Society in England 1750-1900. Harlow: Longman Press, 1996.

Gatrell, V.A.C. The Hanging Tree: Execution and the English People 1770-1868. Oxford: Oxford University Press, 1996.

Griffin, Rachael. "Bobbies, Booze and Bagatelle: Policing Vice in Early Victorian London." In Law, Crime and Deviance since 1700: Micro-Studies in the History of Crime, edited by Anne-Marie Kilday and David Nash, 191-206. London: Bloomsbury Academic Press, 2017.

Hall, Catherine "The Early Formation of Victorian Domestic Ideology." In Gender and History in Western Europe, edited by Robert Shoemaker and Mary Vincent, 181-196. London: Hodder Education, 1998.

Henderson, Tony. Disorderly Women in Eighteenth-Century London: Prostitution and Control in the Metropolis, 1730-1830. Harlow: Longman Press, 1999.

Hill, Bridget. Eighteenth-Century Women: An Anthology. London and New York: Routledge, 1993.

Holford, George P. Letters to the Editor of the Quarterly Review on a Misstatement Contained in the 42D Volume of that work...Relative to the Supposed Ill-success of the General Penitentiary at Millbank. London: Rivington's, 1830.

Hughes, Robert. The Fatal Shore. London: Vintage Books, 2003.

King, Peter. Crime and Law in England 1750-1840. Cambridge: Cambridge University Press, 2006).

King, Peter. Crime, Justice and Discretion in England 1740-1820. Oxford: Oxford University Press, 2000.

Malone, Carolyn. "Women in England 1760-1914: A Social History." Journal of Victorian Culture 12, no. 1 (2007): 132-136.

Marhoefer, Laurie "Lesbianism, transvestitism, and the Nazi state: a microhistory of Gestapo investigation, 1929-1945." American Historical Review 121, no. 6 (2016): 1167-1195.

McBride, Theresa M. The Domestic Revolution: The Modernisation of Household Service in England and France 1820-1920. London: Croom Helm, 1976.

Morgan, Gwenda, and Peter Rushton. Rogues, Thieves and the Rule of Law: The Problem of Law Enforcement in North-East England. London: UCL Press, 1998.

Orr, David. "The Foul Conspiracy to Screen Salisbury and Sacrifice Morton': A Micro-history of Extortion, Resistance and Same Sex Intimacy in Early 
Nineteenth-century London." History: Journal of the Historical Association 103, no. 357 (2018): 571-587.

Orr, David. "Crime Control \& Everyday Life in the Victorian City: The Police and the Public." Cultural and Social History 16, no. 3 (2019): 1-2.

Porter, Roy. English Society in the Eighteenth Century. London: Penguin Books, 1982.

Prothero, Iorwerth J. Artisans and Politics in Early Nineteenth-century London: John Gast and His Times. Grantham: Methuen Press, 1979.

Richards, Cynthia. "Women of Quality: Accepting and Contesting Ideas of Femininity in England, 1690-1760." The Scriblerian and the Kit-Cats 36, no. 2 (2004): 182-183.

Russell, Polly. "Using Biographical Narrative and Life Story Methods to Research Women's Movements: Sisterhood and After." Women's Studies International Forum 35, no. 3 (2012): 132-134.

Shaw, Alan G.L. Convicts and the Colonies, a Study of Penal Transportation from Great Britain and Ireland to Australia and Other Parts of the British Empire. London: Faber and Faber, 1966.

Shoemaker, Robert. "Forty Years of Crime in London." The London Journal 40, no. 2 (2015): 89-105.

Shoemaker, Robert. Prosecution and Punishment: Petty Crime and the Law in London and Rural Middlesex c1660-1725. Cambridge: Cambridge University Press, 1991.

Shoemaker, Robert. Gender in English Society 1650-1850. New York and London: Routledge Taylor and Francis Group, 1998/2013.

Shore, Heather. Artful Dodgers: Youth and Crime in Early 19 ${ }^{\text {th }}$ Century London. Woodbridge: The Boydell Press, 1999/2002.

Thomson, Alistair. "Four Paradigm Transformations in Oral History." The Oral History Review 34, no. 1 (2006): 49-70.

Thompson, Dorothy K. G. British Women in the Nineteenth Century. London: The Historical Association, 1989.

Thompson, Edward P. The Making of the English Working Class. London: Penguin, 1991.

Tobias, John J. Crime and Industrial Society in the Nineteenth Century. London: Pelican Books, 1972.

Trumbach, Randolph. Sex and the Gender Revolution (Volume One); Heterosexuality and the Third Gender in Enlightenment London. Chicago and London: The University of Chicago Press, 1998.

Walkowitz, Judith R. City of Dreadful Delight: Narratives of Sexual Danger in LateVictorian England. London: Virago Press, 1992.

Wiener, Martin J. Reconstructing the Criminal: Culture, Law and Policy in England, 1830-1914. Cambridge: Cambridge University Press, 1990. 


\section{Appendix}

Sample of Women prosecuted for Felony at the Old Bailey (1819-1840)

\begin{tabular}{|c|c|c|c|c|c|c|c|}
\hline $\begin{array}{l}\text { NAME AND } \\
\text { AGE }\end{array}$ & $\begin{array}{l}\text { DATE OF } \\
\text { HEARING }\end{array}$ & $\begin{array}{l}\text { INDICTABLE } \\
\text { OFFENCE } \\
\end{array}$ & VERDICT & $\begin{array}{l}\text { ORIGINAL } \\
\text { SENTENCE }\end{array}$ & $\begin{array}{c}\text { FINAL } \\
\text { SENTENCE }\end{array}$ & $\begin{array}{l}\text { PREVIOUS } \\
\text { OFFENCES }\end{array}$ & MITIGATION OR COMMUTATION GRANTED \\
\hline $\begin{array}{l}\text { Andrews, } \\
\text { Mary Ann } \\
\text { (29) }\end{array}$ & $\begin{array}{c}\text { March } \\
1839\end{array}$ & Larceny & Guilty & $\begin{array}{c}7 \text { Years } \\
\text { Transportation }\end{array}$ & $\begin{array}{c}7 \text { years } \\
\text { Transportation }\end{array}$ & $\begin{array}{l}\text { William Willerman, Police } \\
\text { Constable, produced "a } \\
\text { certificate of the prisoner's } \\
\text { former conviction" at trial }\end{array}$ & No - Transported 6 $6^{\text {th }}$ May 1839 (HO11/12, page 27/15). \\
\hline $\begin{array}{l}\text { Baldwin, } \\
\text { Honor (28) }\end{array}$ & $\begin{array}{c}\text { January } \\
1827\end{array}$ & $\begin{array}{c}\text { Stealing in a } \\
\text { Dwelling House }\end{array}$ & Guilty & Death & $\begin{array}{l}\text { Transportation } \\
\text { for Life }\end{array}$ & $\begin{array}{l}\text { No statement recorded at } \\
\text { trial or on petition }\end{array}$ & $\begin{array}{c}\text { Commutation of death sentence - Transported } 12^{\text {th }} \text { July } 1827 \\
\text { (HO11/6, page } 216) \text {. }\end{array}$ \\
\hline $\begin{array}{l}\text { Bartlett, Ann } \\
\text { (16) }\end{array}$ & $\begin{array}{c}\text { October } \\
1838\end{array}$ & $\begin{array}{l}\text { Receiving Stolen } \\
\text { Good }\end{array}$ & Guilty & $\begin{array}{l}7 \text { years } \\
\text { Transportation }\end{array}$ & $\begin{array}{c}\text { "Pen ty as } 7 \text { year } \\
\text { convict" written } \\
\text { on petition. } \\
\end{array}$ & $\begin{array}{l}\text { Gaoler's report "character } \\
\text { not known" }\end{array}$ & No \\
\hline $\begin{array}{l}\text { Bassett, } \\
\text { Emma }\end{array}$ & $\begin{array}{l}\text { December } \\
1826\end{array}$ & Pickpocketing & Guilty & $\begin{array}{c}14 \text { years } \\
\text { Transportation }\end{array}$ & $\begin{array}{c}14 \text { years } \\
\text { Transportation }\end{array}$ & $\begin{array}{l}\text { No statement recorded at } \\
\text { trial or on petition }\end{array}$ & No - Transported 27th March 1827 (HO11/6, page 137/70). \\
\hline $\begin{array}{l}\text { Brady, } \\
\text { Winifred }\end{array}$ & $\begin{array}{l}\text { August } \\
1838\end{array}$ & $\begin{array}{l}\text { Receiving stolen } \\
\text { Goods }\end{array}$ & Guilty & $\begin{array}{c}6 \text { months } \\
\text { Imprisonment }\end{array}$ & $\begin{array}{c}6 \text { months } \\
\text { Imprisonment }\end{array}$ & None & No \\
\hline $\begin{array}{l}\text { Burtonwood, } \\
\text { Mary (42) }\end{array}$ & $\begin{array}{l}\text { June } \\
1821 \\
\end{array}$ & $\begin{array}{c}\text { Stealing from the } \\
\text { Person }\end{array}$ & Guilty & $\begin{array}{l}\text { Transportation } \\
\text { for Life }\end{array}$ & $\begin{array}{l}\text { Transportation } \\
\text { for Life }\end{array}$ & $\begin{array}{c}\text { "Tried before" (written on } \\
\text { petition) }\end{array}$ & No - Transported 25 $5^{\text {th }}$ December 1821 (HO11/4, page 131/67). \\
\hline $\begin{array}{l}\text { Cooper, } \\
\text { Hannah (21) }\end{array}$ & $\begin{array}{l}\text { July } \\
1819\end{array}$ & Grand Larceny & Guilty & $\begin{array}{l}\text { Gaoler's report } \\
\text { on petition } \\
\text { 'convicted } \\
\text { before'. }\end{array}$ & $\begin{array}{l}\text { Served sentence } \\
\text { at Milbank }\end{array}$ & None & No \\
\hline $\begin{array}{l}\text { Day, Mary } \\
(26)\end{array}$ & $\begin{array}{c}\text { February } \\
1829 \\
\end{array}$ & Simple Larceny & Guilty & $\begin{array}{c}7 \text { years } \\
\text { Transportation } \\
\end{array}$ & $\begin{array}{c}7 \text { years } \\
\text { Transportation } \\
\end{array}$ & None & No - Transported 10 th July 1829 (HO11/7, page 106). \\
\hline $\begin{array}{l}\text { Driscoll, } \\
\text { Elizabeth (34) }\end{array}$ & $\begin{array}{c}\text { January } \\
1827\end{array}$ & $\begin{array}{l}\text { Receiving } \\
\text { Stolen Goods }\end{array}$ & Guilty & $\begin{array}{c}7 \text { years } \\
\text { Transportation }\end{array}$ & $\begin{array}{l}\text { Served sentence } \\
\text { in penitentiary } \\
(\mathrm{HO} / 19 / 5)\end{array}$ & None & No \\
\hline $\begin{array}{l}\text { Field, Mary } \\
\text { Jane (18) }\end{array}$ & $\begin{array}{l}\text { April } \\
1828\end{array}$ & $\begin{array}{l}\text { Larceny (2 } \\
\text { Indictments) }\end{array}$ & $\begin{array}{l}\text { Guilty } \\
\text { of one } \\
\text { charge }\end{array}$ & $\begin{array}{c}7 \text { years } \\
\text { Transportation }\end{array}$ & $\begin{array}{c}7 \text { years } \\
\text { Transportation }\end{array}$ & None & No - Transported 9th June 1828 (HO11/6, page 415/209). \\
\hline $\begin{array}{l}\text { Fillingham, } \\
\text { Maria (46) }\end{array}$ & $\begin{array}{c}\text { December } \\
1826\end{array}$ & Larceny & Guilty & $\begin{array}{c}7 \text { years } \\
\text { Transportation }\end{array}$ & $\begin{array}{c}7 \text { years } \\
\text { Transportation }\end{array}$ & One (stated in petition) & No - Transported 10 $0^{\text {th }}$ April 1827 (HO11/6, page 144). \\
\hline $\begin{array}{l}\text { Freeman, } \\
\text { Sarah (34) }\end{array}$ & $\begin{array}{c}\text { January } \\
1823\end{array}$ & Grand Larceny & Guilty & $\begin{array}{c}7 \text { years } \\
\text { Transportation }\end{array}$ & $\begin{array}{c}7 \text { years } \\
\text { Transportation }\end{array}$ & $\begin{array}{l}\text { No statement recorded at } \\
\text { trial or on petition }\end{array}$ & No - Transported 20 th November 1823 (HO11/5, page 109/56). \\
\hline $\begin{array}{l}\text { Gold, Mary } \\
\text { (29) }\end{array}$ & $\begin{array}{l}\text { April } \\
1828\end{array}$ & Larceny & Guilty & $\begin{array}{c}7 \text { years } \\
\text { Transportation }\end{array}$ & $\begin{array}{c}7 \text { years } \\
\text { Transportation }\end{array}$ & None (stated in the petition) & $\begin{array}{l}\text { No, according to petition, but no record of transportation to } \\
\text { penal colony. No record of sentence served in penitentiary, } \\
\text { although this was requested in the petition. }\end{array}$ \\
\hline $\begin{array}{l}\text { Harrison, } \\
\text { Eliza (30) }\end{array}$ & $\begin{array}{c}\text { February } \\
1828\end{array}$ & Larceny & Guilty & $\begin{array}{c}7 \text { years } \\
\text { Transportation }\end{array}$ & $\begin{array}{c}7 \text { years } \\
\text { Transportation }\end{array}$ & & No - Transported 9 $9^{\text {th }}$ June 1828 (HO11/6, page 415/209). \\
\hline $\begin{array}{l}\text { Haley, Mary } \\
\text { (27) }\end{array}$ & $\begin{array}{l}\text { April } \\
1828\end{array}$ & Larceny & Guilty & $\begin{array}{c}7 \text { years } \\
\text { Transportation }\end{array}$ & $\begin{array}{c}7 \text { years } \\
\text { Transportation }\end{array}$ & $\begin{array}{l}\text { Gaoler's report on petition } \\
\text { "convicted before" }\end{array}$ & No - Transported $9^{\text {th }}$ June 1828 (HO11/6, page 414). \\
\hline
\end{tabular}




\begin{tabular}{|c|c|c|c|c|c|c|c|}
\hline $\begin{array}{l}\text { Holland, } \\
\text { Elizabeth (22) }\end{array}$ & $\begin{array}{c}\text { December } \\
1826\end{array}$ & Larceny & Guilty & $\begin{array}{c}7 \text { years } \\
\text { Transportation }\end{array}$ & "Penitentiary" & None & $\begin{array}{l}\text { Sentence reduced to } 1 \text { year in penitentiary following plea by } \\
\text { Ann Betley. }\end{array}$ \\
\hline $\begin{array}{l}\text { Hopwood, } \\
\text { Sarah (20) }\end{array}$ & $\begin{array}{l}\text { February } \\
1835\end{array}$ & $\begin{array}{l}\text { Theft from a } \\
\text { specified Place }\end{array}$ & Guilty & $\begin{array}{l}7 \text { years } \\
\text { Transportation }\end{array}$ & $\begin{array}{l}7 \text { years } \\
\text { Transportation }\end{array}$ & None & $\begin{array}{c}\text { No - Transported 13 } 3^{\text {th }} \text { April } 1835 \\
\text { https://convictrecords.com.au/convicts/hopwood/sarah/135073. }\end{array}$ \\
\hline $\begin{array}{l}\text { Jackman, } \\
\text { Mary (30) }\end{array}$ & $\begin{array}{l}\text { June } \\
1831\end{array}$ & Robbery & Guilty & Death & $\begin{array}{l}\text { Transportation } \\
\quad \text { for Life }\end{array}$ & $\begin{array}{l}\text { Petitioners testify to "good } \\
\text { character," and no indication } \\
\text { of previous criminal record }\end{array}$ & $\begin{array}{l}\text { Commutation of death sentence - Transported } 4^{\text {th }} \text { December } \\
\qquad 1832 \text { (HO11/8, page } 482) \text {. }\end{array}$ \\
\hline $\begin{array}{l}\text { Jennings, } \\
\text { Elizabeth (22) }\end{array}$ & $\begin{array}{l}\text { June } \\
1820\end{array}$ & $\begin{array}{l}\text { Stealing from the } \\
\text { Person }\end{array}$ & Guilty & $\begin{array}{l}\text { Transportation } \\
\text { for Life }\end{array}$ & $\begin{array}{l}\text { Transportation } \\
\text { for Life }\end{array}$ & None & $\begin{array}{c}\text { No, but was returned from Hulks to Newgate due to ill-health. } \\
\text { Eventually transported } 7^{\text {th }} \text { September } 1822 \text { (HO11/4, Page } \\
199 / 100) \text {. }\end{array}$ \\
\hline $\begin{array}{l}\text { Kenney, } \\
\text { Catherine 16) }\end{array}$ & $\begin{array}{c}\text { January } \\
1835 \\
\end{array}$ & Larceny & Guilty & $\begin{array}{c}7 \text { years } \\
\text { Transportation } \\
\end{array}$ & $\begin{array}{c}7 \text { years } \\
\text { Transportation }\end{array}$ & $\begin{array}{c}\text { Previous conviction(s) - } \\
\text { stated at trial }\end{array}$ & No - Transported 13 $3^{\text {th }}$ April 1835 (HO11/10, page 28). \\
\hline $\begin{array}{l}\text { Lewis, } \\
\text { Elizabeth (35) }\end{array}$ & $\begin{array}{c}\text { January } \\
1825\end{array}$ & $\begin{array}{l}\text { Stealing from the } \\
\text { Person }\end{array}$ & Guilty & $\begin{array}{l}\text { Transportation } \\
\text { for Life }\end{array}$ & $\begin{array}{l}\text { Transportation } \\
\text { for Life }\end{array}$ & $\begin{array}{c}\text { "Once before for stealing } \\
\text { money served } 12 \text { months" } \\
\text { (CON 40/1/5 - Tasmanian } \\
\text { Records) } \\
\end{array}$ & No - Transported 22nd July 1925 (HO11/5, page 279/141). \\
\hline $\begin{array}{l}\text { Lewis, Mary } \\
\text { (23) }\end{array}$ & $\begin{array}{l}\text { February } \\
1839\end{array}$ & Larceny & Guilty & $\begin{array}{l}7 \text { years } \\
\text { Transportation }\end{array}$ & $\begin{array}{l}7 \text { years } \\
\text { Transportation }\end{array}$ & $\begin{array}{l}\text { Known to arresting } \\
\text { constable (William Horsfield) } \\
\text { as "begging-letter impostor" }\end{array}$ & No - Transported 6 $6^{\text {th }}$ May 1839 (HO11/12, page 27/15). \\
\hline $\begin{array}{l}\text { Lowman, } \\
\text { Margaret (23) }\end{array}$ & $\begin{array}{l}\text { December } \\
1826\end{array}$ & Grand Larceny & Guilty & $\begin{array}{l}7 \text { years } \\
\text { Transportation }\end{array}$ & $\begin{array}{c}\text { "Removed to } \\
\text { penitentiary" } \\
\text { where she served } \\
\text { her sentence } \\
(\mathrm{HO} / 19 / 5)\end{array}$ & None & $\begin{array}{l}\text { No indication is given on the petition of why the prisoner was } \\
\text { not transported or "removed to penitentiary." }\end{array}$ \\
\hline $\begin{array}{l}\text { Madden, } \\
\text { Ellen (17) } \\
\end{array}$ & $\begin{array}{c}\text { February } \\
1828 \\
\end{array}$ & $\begin{array}{l}\text { Stealing from the } \\
\text { Person }\end{array}$ & Guilty & $\begin{array}{l}\text { Transportation } \\
\text { for Life }\end{array}$ & $\begin{array}{c}\text { Transportation } \\
\text { for Life }\end{array}$ & $\begin{array}{c}\text { "Gaoler's report - } \\
\text { prostitute" }\end{array}$ & No - Transported 9th June 1828 (HO11/6, page 413/208). \\
\hline $\begin{array}{l}\text { Miller, Emma } \\
\text { (21) }\end{array}$ & $\begin{array}{l}\text { September } \\
1837\end{array}$ & Larceny & Guilty & $\begin{array}{l}7 \text { years } \\
\text { Transportation }\end{array}$ & $\begin{array}{l}\text { "Ordered to pen'y } \\
\text { on recom'n of } \\
\text { court," where } \\
\text { sentence was } \\
\text { served }\end{array}$ & None & No \\
\hline $\begin{array}{l}\text { Morris, } \\
\text { Susannah (16) }\end{array}$ & $\begin{array}{c}\text { April } \\
1829\end{array}$ & Theft from Master & Guilty & $\begin{array}{l}14 \text { days } \\
\text { Imprisonment }\end{array}$ & $\begin{array}{c}14 \text { days } \\
\text { Imprisonment }\end{array}$ & None & No \\
\hline $\begin{array}{l}\text { Short, } \\
\text { Elizabeth (20) }\end{array}$ & $\begin{array}{l}\text { December } \\
1826\end{array}$ & $\begin{array}{l}\text { Originally indicted } \\
\text { for Stealing in a } \\
\text { Dwelling House but } \\
\text { tried for lesser } \\
\text { charge of Stealing } \\
\text { from Master }\end{array}$ & Guilty & $\begin{array}{l}6 \text { months in } \\
\text { House of } \\
\text { Correction }\end{array}$ & $\begin{array}{l}6 \text { months in } \\
\text { House of } \\
\text { Correction }\end{array}$ & None & No \\
\hline $\begin{array}{l}\text { Spice, } \\
\text { Elizabeth (16) }\end{array}$ & $\begin{array}{c}\text { April } \\
1829\end{array}$ & Larceny & Guilty & $\begin{array}{l}7 \text { years } \\
\text { Transportation }\end{array}$ & $\begin{array}{l}\text { Served sentence } \\
\text { in penitentiary } \\
\text { following petition }\end{array}$ & None & No \\
\hline
\end{tabular}


Orr: Women, Pleas and Property Crime: Understanding the Fortunes...

\begin{tabular}{|c|c|c|c|c|c|c|c|}
\hline $\begin{array}{l}\text { Sutton, Clara } \\
(16)\end{array}$ & $\begin{array}{c}\text { January } \\
1827\end{array}$ & $\begin{array}{l}\text { Stealing from the } \\
\text { Person }\end{array}$ & Guilty & $\begin{array}{l}\text { Transportation } \\
\text { for Life }\end{array}$ & $\begin{array}{l}\text { Transportation } \\
\text { for Life }\end{array}$ & None & No - Transported 27th March 1827 (HO11/6, page 138). \\
\hline $\begin{array}{l}\text { Toomey, } \\
\text { Maria (36) }\end{array}$ & $\begin{array}{l}\text { April } \\
1829 \\
\end{array}$ & Larceny & Guilty & $\begin{array}{c}7 \text { years } \\
\text { Transportation } \\
\end{array}$ & $\begin{array}{c}7 \text { years } \\
\text { Transportation }\end{array}$ & None & No - Transported $10^{\text {th }}$ July 1829 (HO11/7, page $\left.107 / 56\right)$. \\
\hline $\begin{array}{l}\text { Warner, } \\
\text { Elizabeth } \\
\text { Ann (30) }\end{array}$ & $\begin{array}{c}\text { April } \\
1829\end{array}$ & Larceny & Guilty & $\begin{array}{c}7 \text { years } \\
\text { Transportation }\end{array}$ & $\begin{array}{c}7 \text { years } \\
\text { Transportation }\end{array}$ & $\begin{array}{l}\text { No statement recorded at } \\
\text { trial or on petition }\end{array}$ & $\begin{array}{l}\text { No outcome recorded but transported } 10^{\text {th }} \text { July for } 7 \text { years } \\
\qquad \text { (HO11/7, page 106). }\end{array}$ \\
\hline $\begin{array}{l}\text { Watson, Ann } \\
(36)\end{array}$ & $\begin{array}{c}\text { February } \\
1835 \\
\end{array}$ & $\begin{array}{c}\text { Receiving Stolen } \\
\text { Goods }\end{array}$ & Guilty & $\begin{array}{c}7 \text { years } \\
\text { Transportation } \\
\end{array}$ & $\begin{array}{c}7 \text { years } \\
\text { Transportation } \\
\end{array}$ & $\begin{array}{c}\text { No statement recorded at } \\
\text { trial or on petition }\end{array}$ & $\begin{array}{l}\text { No outcome on petition recorded but transported } 13^{\text {th }} \text { April } \\
1835 \text { for } 7 \text { years (HO11/10, page } 26 / 16) \text {. }\end{array}$ \\
\hline $\begin{array}{l}\text { West, } \\
\text { Elizabeth (21) }\end{array}$ & $\begin{array}{c}\text { February } \\
1839\end{array}$ & Larceny & Guilty & $\begin{array}{c}7 \text { years } \\
\text { Transportation }\end{array}$ & $\begin{array}{c}7 \text { years } \\
\text { Transportation }\end{array}$ & $\begin{array}{c}\text { "She had been before } \\
\text { convicted of felony" - stated } \\
\text { at trial }\end{array}$ & No - Transported $6^{\text {th }}$ May 1839 (HO11/12, page 27/15). \\
\hline $\begin{array}{l}\text { West, } \\
\text { Hannah (35) }\end{array}$ & $\begin{array}{c}\text { December } \\
1826\end{array}$ & $\begin{array}{c}\text { Stealing in a } \\
\text { Dwelling House }\end{array}$ & Guilty & $\begin{array}{c}7 \text { years } \\
\text { Transportation }\end{array}$ & $\begin{array}{c}7 \text { years } \\
\text { Transportation }\end{array}$ & None & No - Transported 12 $2^{\text {th }}$ May 1827 (HO11/6, page 177/90). \\
\hline $\begin{array}{l}\text { Wheatley, } \\
\text { Elizabeth (17) }\end{array}$ & $\begin{array}{c}\text { December } \\
1826\end{array}$ & Larceny & Guilty & $\begin{array}{c}7 \text { years } \\
\text { Transportation }\end{array}$ & $\begin{array}{l}\text { "Removed to } \\
\text { Penitentiary" }\end{array}$ & None & Was not transported due to poor mental health. \\
\hline $\begin{array}{l}\text { Williams, } \\
\text { Ann (36) }\end{array}$ & $\begin{array}{c}\text { October } \\
1835 \\
\end{array}$ & $\begin{array}{l}\text { Coining } \\
\text { Offences }\end{array}$ & Guilty & $\begin{array}{c}3 \text { years } \\
\text { Imprisonment }\end{array}$ & $\begin{array}{c}3 \text { years } \\
\text { Imprisonment }\end{array}$ & $\begin{array}{c}\text { No statement recorded at } \\
\text { trial or on petition }\end{array}$ & No \\
\hline $\begin{array}{l}\text { Williams, } \\
\text { Maria (19) }\end{array}$ & $\begin{array}{c}\text { January } \\
1824\end{array}$ & $\begin{array}{c}\text { Uttering a } \\
\text { Forged } £ 5 \text { note }\end{array}$ & Guilty & Death & $\begin{array}{l}\text { Transportation } \\
\text { For Life }\end{array}$ & $\begin{array}{l}\text { No statement recorded at } \\
\text { trial or on petition }\end{array}$ & $\begin{array}{l}\text { Commutation of death sentence - Transported } 25^{\text {th }} \text { September } \\
\qquad 1824(\mathrm{HO} 11 / 5 \text {, page } 182) .\end{array}$ \\
\hline $\begin{array}{l}\text { Wilson, Mary } \\
(26)\end{array}$ & $\begin{array}{c}\text { October } \\
1826\end{array}$ & $\begin{array}{l}\text { Stealing from a } \\
\text { Shop }\end{array}$ & Guilty & $\begin{array}{c}14 \text { years } \\
\text { Transportation }\end{array}$ & $\begin{array}{c}14 \text { years } \\
\text { Transportation }\end{array}$ & None & $\begin{array}{l}\text { No outcome on petition recorded but transported 27th } \text { March } \\
1827 \text { for } 14 \text { years (HO11/6, page 135). }\end{array}$ \\
\hline $\begin{array}{l}\text { Wright, Mary } \\
(49)\end{array}$ & $\begin{array}{c}\text { October } \\
1836\end{array}$ & $\begin{array}{c}\text { Larceny (3 } \\
\text { indictments) }\end{array}$ & Guilty & $\begin{array}{c}7 \text { years } \\
\text { Transportation }\end{array}$ & $\begin{array}{c}7 \text { years } \\
\text { Transportation }\end{array}$ & $\begin{array}{l}\text { Gaoler's report on petition } \\
\text { "convicted before." }\end{array}$ & $\begin{array}{l}\text { No - Transported 28 }{ }^{\text {th }} \text { December } 1836 \text { (HO11/10, page } \\
443 / 224) .\end{array}$ \\
\hline
\end{tabular}

